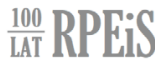

\section{ROLA CZASOPISM NAUKOWYCH W ZREFORMOWANYM SYSTEMIE NAUKI I SZKOLNICTWA WYŻSZEGO W POLSCE}

\section{WSTĘP}

Ustawa z 20 lipca 2018 r. - Prawo o szkolnictwie wyższym i nauce ${ }^{1}$ (popularnie określana jako ustawa 2.0) przesądziła o zmianie regulacji obowiązujacych w sferze nauki i szkolnictwa wyższego w Polsce, w tym także odnoszących się do ewaluacji działalności naukowej prowadzonej w ramach dyscyplin, której ważnym składnikiem jest ocena czasopism. Gdyby spojrzeć na rolę czasopism $\mathrm{z}$ tak zawężonego punktu widzenia, to dałaby się ona sprowadzić do dyskusji na temat nowego wykazu czasopism naukowych sporządzonego na podstawie art. 267 ust. 2 pkt 2 lit. b, a także art. 267 ust. 3 ustawy 2.0 oraz ich wyceny punktowej ustalonej w komunikacie Ministra Nauki i Szkolnictwa Wyższego z 18 grudnia 2019 r. Autorzy tego opracowania przyjmuja jednak w punkcie wyjścia podejście znacząco szersze, wychodząc z założenia, że roli odgrywanej przez czasopisma naukowe nie należy redukować wyłącznie do funkcji ewaluacyjnych. Wydaje się, że proponowane szersze spojrzenie na miejsce czasopism naukowych w systemie nauki i szkolnictwa wyższego w Polsce jest podejściem bardziej adekwatnym, gdyż podchodzi do analizowanej kwestii całościowo, systemowo i pozwala ująć złożoność kontekstu, w jakim odbywa się niekiedy nadmiernie fetyszyzowana ocena czasopism. Dodatkowo akcentuje też tło historyczne i ewolucyjny charakter zmian w dłuższej perspektywie czasowej.

Krytyka prowadzona w środowisku akademickim rozwiązań normatywnych przyjętych przez ustawodawcę w ustawie 2.0 rodzi fundamentalne py-

* Marian Gorynia, Uniwersytet Ekonomiczny w Poznaniu, marian.gorynia@ue.poznan.pl, https://orcid.org/0000-0002-7633-8249.

** Bronisław Sitek, SWPS Uniwersytet Humanistycznospołeczny w Warszawie, bsitek@swps.edu.pl, https://orcid.org/0000-0002-7365-6954.

1 T.jedn.: Dz. U. 2020, poz. 85 (dalej jako: u.s.w.i.n.). 
tanie o to, co należałoby zrobić z obecnie funkcjonującym w Polsce systemem oceny czasopism. Pochodna tego pytania sa kolejne dwa, a mianowicie: jaka winna być rola czasopism w polskim systemie badań naukowych? Oraz czy krytyka obecnego stanu rzeczy powinna prowadzić do radykalnych zmian, czy tė̇ należy raczej przyjąć ewolucyjną koncepcję zmian? Sformułowanie odpowiedzi na dwa ostatnie pytania pozwoli na zbudowanie odpowiedzi na pierwsze.

$\mathrm{Na}$ podstawie przyjętych przez ustawodawcę rozwiązań w rozporządzeniu Ministra Nauki i Szkolnictwa Wyższego z 22 lutego 2019 r. w sprawie ewaluacji jakości działalności naukowej² rola czasopism w węższym tego słowa znaczeniu, sprowadzonym do funkcji ewaluacyjnej, winna być równolegle usytuowana na tle obowiązującego systemu ewaluacji nauki, w którym to systemie czasopisma są jednym z najważniejszych elementów. Uzasadnia to dokonanie krótkiego przeglądu możliwych wariantów systemu ewaluacji nauki oraz określenie silnych i słabych stron systemu przyjętego w Polsce.

Dopiero uwzględnienie obu wyżej zasygnalizowanych uwikłań kontekstualnych roli pełnionej przez czasopisma naukowe pozwala na przeprowadzenie oceny tejże roli w systemie ewaluacji nauki i szkolnictwa wyższego w Polsce. Zdaniem autorów takie postępowanie analityczne powinno dać możliwość uniknięcia ocen skrajnych, wyrwanych z kontekstu i oderwanych od praktyki funkcjonowania czasopism. Innymi słowy, ocena spełniania funkcji ewaluacyjnej przez obecny system oceny czasopism winna być powiązana z krytyczna analizą obowiąujacych rozwiązań oraz zaproponowaniem stosownych zmian.

Jeśli chodzi o stronę metodyczną przygotowania tego opracowania, to główną rolę odegrała krytyczna analiza literatury przedmiotu oraz krytyczna analiza i ocena obowiązujacych regulacji prawnych. Ponadto w prowadzonych rozważaniach wykorzystano elementy podejścia diagnostycznego (opis i ocena dotychczasowych rozwiązań) oraz prognostycznego/ prospektywnego (zarys propozycji zmian dotychczasowych rozwiązań). Dodatkowo w pracy zastosowana została metoda analizy prawnodogmatycznej przepisów prawa, pozwalająca na krytyczną ocenę zamiarów ustawodawcy.

\section{FUNKCJE CZASOPISM NAUKOWYCH W SYSTEMIE NAUKI I SZKOLNICTWA WYŻSZEGO}

Czasopisma naukowe spełniają w systemie nauki i szkolnictwa wyższego liczne i zróżnicowane funkcje. Do najważniejszych z nich należy zaliczyć funkcję naukotwórcza, funkcję popularyzatorsko-promocyjna, funkcję ewaluacyjna oraz pozostałe funkcje. Znaczenie poszczególnych funkcji zmienia się w czasie, ponadto cechuje się niekiedy istotnym zróżnicowaniem w przekroju poszczególnych grup dyscyplin naukowych, a także poszczególnych krajów. Warto zauważyć, że pomiędzy pełnieniem poszczególnych funkcji występują określone powią-

2 Dz. U. 2019, poz. 392 (dalej jako: rozporządzenie). 
zania, a nawet sprzężenia zwrotne, co sprawia, że łącznie mają one właściwości całościowe, systemowe. W rezultacie budowanie systemu czasopism naukowych jest zazwyczaj procesem długotrwałym, ewolucyjnym i z trudem poddajacym się imitacji. Przywołane okoliczności są istotne, zwłaszcza w sytuacji diagnozy rozwiązań już wypracowanych i wdrożonych oraz projektowania zmian.

\section{Funkcja naukotwórcza czasopism: kreator dyskusji naukowej, miejsce prezentacji wyników badań, krytyka naukowa}

Jeśli chodzi o funkcje pełnione przez czasopisma naukowe w systemie nauki i szkolnictwa wyższego, to z pewnością na pierwsze miejsce wysuwa się ich funkcja naukotwórcza. Recenzowane czasopisma naukowe są miejscem prezentacji, oceny i krytyki wyników badań naukowych - są więc niezwykle ważnym ogniwem w prowadzeniu działalności naukowej. Najważniejszym, w pewnym sensie pierwotnym aspektem badań naukowych jest ich przygotowanie i przeprowadzenie. Warto przypomnieć oczywistą okoliczność, że rozpoczynanie jednych badań zazwyczaj nawiązuje do badań już ukończonych, których wyniki zostały opublikowane między innymi w czasopismach naukowych. W tym sensie w danym konkretnym procesie badawczym czasopisma pojawiają się już na etapie przygotowawczym do prowadzenia badania. Czasopisma pełnią też ważną rolę w toku prowadzenia badań, służąc do komunikowania w środowisku naukowym samej koncepcji badań oraz będąc kanałem informowania o czastkowych, etapowych wynikach badań. Czasopisma, spełniajacc wspomniane wyżej funkcje, nie są oczywiście jedynym środkiem komunikacji naukowców z otoczeniem, ale zazwyczaj ich renoma sprawia, że sa jednym z najważniejszych, najbardziej efektywnych i najbardziej poważanych sposobów docierania do środowiska naukowego i szerzej całego otoczenia zainteresowanego wynikami prac badawczych.

Warto podkreślić, że to właśnie na łamach czasopism odbywa się zazwyczaj dyskusja na temat ontologii wycinka rzeczywistego świata stanowiącego przedmiot zainteresowania konkretnej dyscypliny (dyscyplin) nauki. Także czasopisma naukowe sa przeważnie najważniejszym forum, na którym rozpatrywane są główne kwestie epistemologiczne właściwe poszczególnym naukom. Wreszcie czasopisma naukowe sa forum szeroko wykorzystywanym do rozwijania dyskusji na tematy związane z metodologia prowadzenia badań. Czasopisma są więc najczęściej platformą proponowania, dyskutowania, uzgadniania i wypracowywania podstaw filozoficznych badań prowadzonych w poszczególnych dziedzinach i dyscyplinach nauki, a także badań o charakterze interdyscyplinarnym, multidyscyplinarnym i transdyscyplinarnym ${ }^{3}$.

Trudną do przecenienia funkcję spełnianą przez czasopisma stanowi funkcja krytyki naukowej. Krytyka naukowa jest swoistym filtrem dokonujacym selekcji wyników badań - w tym sensie badania dzielą się na te, które zasługują na publikację, i na te, które - zdaniem recenzentów - nie nadaja się do publikacji. Pomijając wszelkie możliwe niedoskonałości, jakie moga pojawiać

\footnotetext{
${ }^{3}$ Gorynia, Jankowska (2017); Gorynia (2021).
} 
się w procedurach recenzowania, można powiedzieć, że czasopisma naukowe są w dużym stopniu odpowiedzialne za zaliczanie jednych wyników badań do nauki oraz za odmówienie takiej kwalifikacji innym.

\section{Funkcja popularyzatorsko-promocyjna czasopism}

Często bywa tak, że czasopisma odznaczają się określonymi orientacjami teoretycznymi, co w praktyce oznacza, że sa z definicji zainteresowane popularyzacja, promocją i nagłaśnianiem wyników badań prowadzonych w ramach zdefiniowanej szkoły badawczej, paradygmatu badawczego, a nawet nurtu metodologicznego. Takie zdefiniowanie profilu czasopisma przez jego wydawcę nie wyklucza pełnienia przez nie funkcji naukotwórczej, z tym że jednak w takim wypadku funkcja ta ma specyficzny i ograniczony charakter, skupia się bowiem tylko na wyodrębnionym segmencie badawczym w ramach dyscypliny czy dziedziny nauki.

Można mieć wątpliwości, czy pełnienie przez czasopisma funkcji popularyzatorsko-promocyjnej w podanym wyżej znaczeniu jest w każdych okolicznościach funkcjonalne społecznie. Wydaje się, że odgrywanie przez czasopisma pozytywnej roli w zakresie popularyzacji i promocji określonych orientacji badawczych jest możliwe w warunkach zapewnienia pluralizmu szkół, ośrodków i środowisk badawczych, czyli innymi słowy: w warunkach wolności prowadzenia badań naukowych. Należy podkreślić, że ważnym czynnikiem sprzyjającym spełnieniu powyższych wymogów jest otwarcie nauki w skali międzynarodowej. Swobodny przepływ myśli naukowej $\mathrm{w}$ otoczeniu międzynarodowym jest najbardziej efektywnym i najbardziej skutecznym sposobem stworzenia pluralizmu podejść badawczych oraz swoistej konkurencji pomiędzy nimi prowadzącej do postępu w nauce w drodze wyłaniania się spośród nich tych, które na dłuższą metę prowadzą do uzyskania najbardziej użytecznych społecznie wyników.

\section{Funkcja ewaluacyjna: rola czasopism w systemie ewaluacji nauki}

Zgodnie z art. 267 ust. 1 pkt 1 u.s.w.i.n. system ewaluacji nauki w Polsce obejmuje trzy komponenty/ kryteria ${ }^{4}$ :

- poziom naukowy lub artystyczny prowadzonej działalności;

- efekty finansowe badań naukowych i prac rozwojowych; darki.

- wpływ działalności naukowej na funkcjonowanie społeczeństwa i gospo-

Zgodnie z $\S 8$ rozporządzenia w ramach pierwszego kryterium oceniane będą:

- artykuły naukowe opublikowane w czasopismach naukowych i w recenzowanych materiałach z międzynarodowych konferencji naukowych, zamieszczonych w wykazie czasopism;

\footnotetext{
${ }^{4}$ Podane w tym podrozdziale informacje zostały pobrane ze strony: $<$ https://konstytucjadlanauki.gov.pl/ewaluacja\#kryteria>.

5 Skoczeń (2019).
} 
- artykuły naukowe opublikowane w czasopismach naukowych niezamieszczonych w wykazie czasopism;

- monografie naukowe wydane przez wydawnictwa zamieszczone w wykazie wydawnictw, redakcje naukowe takich monografii i autorstwo rozdziałów w takich monografiach;

- monografie naukowe wydane przez wydawnictwa niezamieszczone w wykazie wydawnictw, redakcje naukowe takich monografii i autorstwo rozdziałów w takich monografiach;

- patenty na wynalazki, prawa ochronne na wzory użytkowe i wyłączne prawa do odmian roślin.

W odniesieniu do drugiego kryterium ( $\$ 22$ ust. 1 rozporządzenia) będą brane pod uwagę następujące osiagnięcia:

- projekty obejmujące badania naukowe lub prace rozwojowe finansowane w trybie konkursowym przez instytucje zagraniczne lub organizacje międzynarodowe, a także przez NCN i NCBR;

- projekty finansowane w ramach Narodowego Programu Rozwoju Humanistyki;

- komercjalizacja wyników badań naukowych, prac rozwojowych lub know-how związanego z tymi wynikami;

- usługi badawcze świadczone na zlecenie podmiotów nienależących do systemu szkolnictwa wyższego i nauki.

Jeśli chodzi o trzecie kryterium, to ocena wpływu działalności naukowej na funkcjonowanie społeczeństwa i gospodarki (§ 23 rozporządzenia) będzie przeprowadzona na podstawie opisów udowadniających związek między badaniami a funkcjonowaniem administracji, ochroną zdrowia, kulturą itp. Przy ocenie tego kryterium bierze się pod uwagę tzw. studium indywidualnych przypadków, które pozwala na rzetelny pomiar i ocenę wpływu.

Warto podkreślić, że wymienionym kryteriom przypisano różne wagi w zależności od tego, z jaką grupą nauk mamy do czynienia, przy czym wyróżniono cztery grup nauk: humanistyczne, społeczne i teologiczne; ścisłe, przyrodnicze, medyczne i o zdrowiu; inżynieryjne, techniczne, rolnicze oraz dyscypliny artystyczne.

Z powyższego wynika, że w systemie ewaluacji nauki ważną rolę odgrywają czasopisma - są one elementem kryterium pierwszego, które we wszystkich czterech grupach nauk ma przypisaną wagę od 50-80\%.

\section{Inne funkcje czasopism naukowych ${ }^{6}$}

Czasopisma naukowe pełnią też liczne inne funkcje, najczęściej powiązane z omówionymi wyżej. Z funkcją naukotwórczą koresponduje pobudzanie aktywności naukowej i dydaktycznej oraz możliwość podzielenia się własnymi

\footnotetext{
${ }^{6}$ Część podanych w tym podpunkcie przemyśleń pochodzi z wywiadu przeprowadzonego przez autorów z prof. Maciejem Zabelem, przewodniczącym Komitetu Ewaluacji Jednostek Naukowych w kadencji 2010-2019. Wprawdzie uwagi prof. Zabela odnosiły się do czasopism medycznych, ale tutaj przyjmuje się, że większość z nich można odnieść do ogółu pism naukowych.
} 
osiagnięciami. Czasopisma sa rzetelnym źródłem informacji, które przechodzi proces recenzji i weryfikacji. Dają też możliwość rzeczywistej i szczegółowej wymiany doświadczeń naukowych, gdyż na konferencjach naukowych przekazywane sa w zasadzie tylko wstępne i ogólne informacje o nowościach. Pisma naukowe stwarzaja możliwość poznania ośrodków pracujących nad podobnymi zagadnieniami i możliwość konfrontowania wyników własnych badań. Warto podkreślić, że o ile do lat osiemdziesiątych XX w. czasopisma stanowiły właściwie jedyne źródło aktualnej i rzetelnej informacji naukowej, o tyle później nastapiło $\mathrm{z}$ tego punktu widzenia zmniejszenie ich znaczenia $\mathrm{z}$ powodu rozwoju innych mediów informatycznych, głównie internetowych.

Czasopisma dają też szybką możliwość zebrania aktualnej wiedzy na określony temat przez tworzenie zeszytów (tomów) specjalistycznych, stając się $\mathrm{w}$ ten sposób niezastapionym forum wymiany naukowej. Umożliwiają one także śledzenie rozwoju wiedzy na określony temat w układzie historycznym, zwłaszcza przez powoływanie się na piśmiennictwo wcześniejsze. Odznaczaja się ponadto łatwością przekazywania wiedzy i własnych osiagnięć między naukowcami. W pewnym zakresie czasopisma naukowe można traktować jako cenną alternatywę dla Wikipedii i Facebooka (oraz podobnych mediów), co wiąże się przede wszystkim z profesjonalną weryfikacją rozpowszechnianych treści.

Czasopisma pozwalają na szybki dostęp do najnowszych rozwiązań czy myśli pochodzących często z drugiej strony globu. Proces ten jest wspomagany przez dość powszechne publikowanie artykułów w publikatorach określanych jako open access journals ${ }^{7}$. Narzędziem ułatwiającym i wspomagającym dostęp do najnowszych artykułów są wyszukiwarki internetowe, takie jak m.in: Google Scholar, ResearchGate czy Academia.edu.

Należy jednak podkreślić, że swoisty międzynarodowy albo nawet światowy rynek czasopism naukowych nie jest wolny od ułomności związanych z funkcjonowaniem wszelkich rynków. Chodzi tutaj zwłaszcza o różnego rodzaju „manipulacje” związane z promowaniem wartości czasopism, np. przez sztuczne i nierzetelne podnoszenie wartości wskaźnika impact factor (IF) i innych parametrów. Wskazane nieprawidłowości nie mogą jednak przesłaniać przewagi funkcji pozytywnych spełnianych przez czasopisma naukowe.

\section{Syntetyczna ocena systemu czasopism naukowych w Polsce}

System czasopism naukowych w Polsce posiada zarówno mocne, jak i słabe strony, przy czym niektóre cechy tego systemu mają dualny charakter, jednocześnie stanowiąc potencjalnie silną i słabą stronę. Tak jest bodajże z najważniejszą cechą tego systemu, jaką z jednej strony stanowi liczba wydawanych w Polsce czasopism naukowych, a z drugiej - liczba czasopism uwzględnionych

\footnotetext{
${ }^{7}$ Warto w tym miejscu wspomnieć o Directory of Open Access Journals (DOAJ): międzynarodowej bazie rejestrującej recenzowane czasopisma naukowe, do których dostęp jest darmowy. Polskich czasopism nie ma tam wiele (między 600 a 650) w porównaniu z innymi państwami, ale sa tam obecne, a kilka ma nawet status DOAJ Seal, będący wyrazem uznania stosowania przez pismo dobrych praktyk.
} 
w nowym wykazie ${ }^{8}$. Z jednej strony podkreśla się, że liczba czasopism związanych z nauką polska jest relatywnie duża. Oznacza to, że co do zasady w systemie nauki i szkolnictwa wyższego w Polsce występują niezłe możliwości publikowania. Jednak z faktu istnienia znacznej całkowitej liczby czasopism nie można wysnuwać wniosków na temat pokrycia przez wydawane czasopisma poszczególnych dziedzin i dyscyplin nauki. Pod tym względem istnieją zauważalne rozpiętości w odniesieniu do różnych pól działalności naukowej.

Drugą cechą systemu czasopism naukowych w Polsce jest ich znaczne rozproszenie. W niektórych dziedzinach i obszarach nauki występuje znaczna liczba czasopism, które posiadają dość wąski krag odbiorców oraz jeszcze węższy krąg naukowców zainteresowanych publikacjami w nich. Część czasopism związana jest z określonymi jednostkami nauki i szkolnictwa wyższego (jednostki naukowo-badawcze, uczelnie wyższe itp.) i w pierwszej kolejności nastawiona na obsługę własnych pracowników. Postępujacy proces otwierania się na podaż zewnętrzną publikowanych materiałów nie doprowadził jednak dotychczas w tendencji do zadowalającej sytuacji pod tym względem. Wspomnianemu rozproszeniu czasopism towarzyszy - co zrozumiałe - relatywnie słaba pozycja międzynarodowa większości z nich. Wiąże się to głównie z faktem, że językiem publikacji czasopism wydawanych w Polsce jest w zdecydowanej większości język polski, choć należy też zauważyć zmiany w tym zakresie i dostrzec istnienie czasopism zarówno w całości wydawanych w językach obcych (głównie angielskim), jak i w formule mieszanej (część artykułów w języku polskim, a część w języku obcym, przeważnie angielskim).

Należy pamiętać, że umiędzynarodowienie czasopism winno być prowadzone z jednoczesnym respektowaniem badań prowadzonych w ośrodkach peryferyjnych. Rankingi uniwersyteckie, centralne programy finasowania badań naukowych często prowadzą do zaniedbywania badań nad lokalnymi i regionalnymi zagadnieniami na rzecz publikacji zamieszczanych w czasopismach międzynarodowych. To wielkie centra naukowe, w tym i twórcy rankingów

${ }^{8}$ W Polsce wydawanych jest ponad 2200 czasopism naukowych - według najnowszych dostępnych danych w roku 2018 było ich 2221 . W'́ród czasopism naukowych $40 \%$ stanowiły periodyki wydawane w języku polskim, 45\% - łączące język polski i obcy, a 15\% - publikowane w całości w języku obcym. W grupie tych ostatnich $94 \%$ to pisma publikowane po angielsku, po $1,5 \%-$ pisma francusko- i niemieckojęzyczne, po 0,6\% - wydawane w języku słowackim, hiszpańskim i ukraińskim (Ruch wydawniczy w liczbach 2019, Warszawa: Biblioteka Narodowa 2019: 15). W 2020 r. w bazach Scopus i Web of Science zindeksowanych było kilkaset polskich czasopism. Ponad 100 z nich wydawanych było w języku polskim (np. „Język Polski”, „Filozofia Nauki” czy „Przegląd Strategiczny”). W wykazie czasopism uwzględnianych w procesie ewaluacji ostatecznie ujęto 30676 pozycji (czasopism naukowych jest 29 037, a materiałów z konferencji - 1639). Stanowi to wzrost o ponad $61 \% \mathrm{w}$ stosunku do starego wykazu czasopism ogłoszonego w styczniu 2017 r. Poprzedni wykaz obejmował 19014 tytułów, <https://konstytucjadlanauki.gov.pl/koniec-z-punktoza-nowy-wykaz-czasopism-juz-jest>. Najnowszy wykaz czasopism (z grudnia 2019) obejmuje 30404 czasopisma naukowe (wzrost o 1373 czasopisma w stosunku do wykazu opublikowanego 31 lipca 2019), w tym 1209 czasopism nowo przyjętych do bazy Scopus lub baz WoS, oraz 164 czasopisma nowo przyjęte do bazy ERIH+, które uzyskały pozytywną ocenę KEN, <https://www.gov.pl/ web/edukacja-i-nauka/nowe-rozszerzone-wykazy-czasopism-naukowych-i-recenzowanych-materialow-z-konferencji-miedzynarodowych-oraz-wydawnictw-monografii-naukowych>. 
czasopism naukowych, decydują o tym, które badania zasługują na międzynarodowe uznanie, a które są marginalizowane ${ }^{9}$.

W systemie czasopism wydawanych w Polsce na uwage zasługuje osobna kategoria czasopism, jaka stanowią czasopisma wydawane przez towarzystwa naukowe ${ }^{10}$. Czasopisma te sa przykładem jednoczesnego spełniania wielu funkcji, przy czym ważnym aspektem prowadzonej przez towarzystwa naukowe działalności jest funkcja naukotwórcza ${ }^{11}$. Iwona Hofman podkreśla, że czasopisma te są elementem kultury, oraz zauważa, że „Są [...] nie tylko nośnikiem informacji naukowej, przekaźnikiem treści w międzynarodowym dialogu naukowym, lecz także symbolicznym atrybutem rozwoju społeczeństw doceniających tzw. transfer wiedzy"12.

\section{SYSTEM EWALUACJI NAUKI JAKO KONTEKST ROLI PELNIONEJ PRZEZ CZASOPISMA NAUKOWE}

Pamiętając o wcześniej zauważonej okoliczności, że czasopisma naukowe pełnią funkcje znacznie wykraczające poza samą funkcję ewaluacyjna, warto poświęcić nieco uwagi możliwym modelowym rozwiązaniom w zakresie koncepcji systemu ewaluacji nauki. W tym zakresie daje się wyróżnić dwa typy czyste oraz trzeci typ, stanowiący mieszankę obu typów czystych ${ }^{13}$. Pierwszy typ to system oznaczajacy pełną kwantyfikację dorobku ocenianych jednostek naukowych. Typ drugi bazuje na ocenie eksperckiej tychże jednostek. Wreszcie $\mathrm{w}$ typie trzecim mamy do czynienia $\mathrm{z}$ rozwiązaniem hybrydowym, które koncepcyjnie czerpie w różnych możliwych proporcjach z rozwiązań ewaluacyjnych obecnych w typie pierwszym i drugim. W zależności od przyjętych proporcji daje się więc wyróżnić większą liczbę rozwiązań mieszanych.

Należy podkreślić, że idea kwantyfikacji dorobku przyświecała twórcom polskich reform nauki i szkolnictwa wyższego od wczesnych lat dziewięćdziesiątych XX w. Takie podejście było swego rodzaju odreagowaniem na uznaniowość, a czasami nawet woluntaryzm cechujący rozwiązania obowiązujące przed rokiem 1990. W czystej wersji tego systemu jego zwolennicy zdają się zapominać o znanym spostrzeżeniu Alberta Einsteina, że nie wszystko, co ważne, daje się zmierzyć oraz nie wszystko, co daje się zmierzyć, jest ważne (w oryginalnej wersji: „Czasem jest tak, że to, co się liczy, nie da się policzyć, a to, co daje się policzyć - nie liczy się"). Pomiarowi poddawane sa wszystkie uznane za ważne aspekty/ wymiary dorobku generowanego przez poszczegól-

9 Kozłowski (2010): 106.

${ }^{10}$ Kansy (2017).

11 Jak podaje Kansy (2017: 9): „Około 80\% czasopism wydawanych przez towarzystwa naukowe znajduje się na listach czasopism punktowanych Ministerstwa Nauki i Szkolnictwa Wyższego, co można odebrać jako wyraz ambicji i potrzeb zbiorowości tworzących poszczególne towarzystwa”.

12 Hofman (2017): 24.

13 Kulczycki (2016). 
ne jednostki sektora nauki. Przyjmuje się założenie, że nie tylko każdy aspekt/ wymiar daje się wyrazić liczbowo, ale także wyniki oceny poszczególnych elementów daje się sumować, co pozwala na dokonanie jednej syntetycznej oceny ${ }^{14}$. Wyniki tak przeprowadzonej ewaluacji daje się ułożyć w ranking, a jednostki z podobnymi ocenami mogą być przyporządkowane do poszczególnych kategorii wyodrębnionych w ramach rankingu ${ }^{15}$.

Wyniki takiej ewaluacji sa jednoznaczne i przejrzyste. Z tego punktu widzenia można stwierdzić, że zaletą takiego sposobu ewaluacji jest możliwość i łatwość wykorzystania jej wyników do finansowania nakładów na badania naukowe (przynajmniej w części obejmującej koszty stałe czy koszty podstawowe funkcjonowania konkretnej jednostki naukowej; osobnym zagadnieniem jest pozyskiwanie środków na badania w drodze konkursowej) oraz do określenia uprawnień do nadawania stopni naukowych (przy spełnieniu innych dodatkowych warunków).

Należy zauważyć, że omawiany typ systemu ewaluacji nie jest beznakładowy ${ }^{16}$. Nakładów wymaga opracowanie koncepcji systemu, ustalenie wag poszczególnych składników oceny oraz wycena poszczególnych elementów dorobku. Ewidencjonowanie dorobku, jego zliczanie i wycena dla poszczególnych jednostek wymagają stworzenia systemu informatycznego, który też kosztuje. Niezbędny jest także znaczny wysiłek organizacyjny i niemałe nakłady czasu pracy pracowników ocenianych jednostek.

System ekspercki ewaluacji osiagnięć naukowych nawiązuje do indywidualnej oceny eksperckiej poszczególnych osiagnięć naukowych poszczególnych jednostek naukowych, a w skali mikro - poszczególnych osiagnięć naukowych, a także wyników indywidualnych pracowników nauki ${ }^{17}$. Możliwości i sposób jego wykorzystania w zależności od tego, co jest oceniane, są oczywiście zróżnicowane. Ekspercki system oceny ma w każdym z tych kontekstów określone wady i zalety. W prowadzonych dyskusjach środowiskowych podkreśla się, że ewaluacja całkowicie lub prawie całkowicie ekspercka jest w warunkach polskich nierealna z wielu powodów. Podstawowe znaczenie ma brak kompetentnych ekspertów krajowych dobrze przygotowanych do pełnienia tej funkcji ${ }^{18}$, a z kolei eksperci zagraniczni nie sa zbytnio zainteresowani tą aktywnością. Podejście eksperckie generuje do tego olbrzymie koszty. Można sformułować prawidłowość, że im większy element do oceny, tym rola ekspertów musi się zmniejszać na korzyść parametryzacji. Ewaluacja dorobku indywidualnego naukowca lub określonej grupy naukowców może bazować na ocenie eksperckiej, ale już porównanie i ustalenie kategorii w całej dyscyplinie, np. nauki medyczne w całym kraju i przyrównanie tych kategorii do innych dyscyplin, musi zasadniczo opierać się na ocenie parametrycznej. Należy bowiem przy

\footnotetext{
${ }^{14} \mathrm{Na}$ watpliwości związane z przyjęciem takiego podejścia wskazywał między Tadeusz Wawak (2019a: 29-35).

15 Kulczycki (2019).

16 Kulczycki (2016).

17 Kulczycki (2016); Kulczycki, Rozkosz, Drabek (2016).

18 Jak podkreśla prof. Zabel, Komitet Ewaluacji Jednostek Naukowych zetknął się z tym problemem w znacznej skali.
} 
tym zauważyć, że w wypadku oceny osiagnięć szerszych zbiorowości (uczelni, wydziałów, instytutów itp.) i tak zawsze powstaje na końcu problem porównywalności uzyskanych wyników oceny eksperckiej dla poszczególnych jednostek, w więc ostatecznie niezbędne staje się wykorzystanie jakiejś odmiany oceny parametrycznej. Dodatkowo trzeba podkreślić, że trudno jest stworzyć jeden system oceny wykorzystywany do kilku celów. System poprzedzający wprowadzenie ustawy 2.0 miał służyć zasadniczo jedynie do rozdziału finansowania statutowego, natomiast obecny ma służyć również wielu innym celom, a w szczególności ma stanowić podstawę do uzyskiwania uprawnień do nadawania stopni naukowych.

O ile system parametryczny i system ekspercki mogą być uznane za systemy czyste, o tyle w rzeczywistości mamy zazwyczaj do czynienia z systemami ewaluacji, które różnią się między sobą proporcją wykorzystania narzędzi parametrycznych i eksperckich. Systemy mieszane dają możliwość optymalizacji silnych i słabych stron systemów „,zystych”, ale im więcej przesunięcia w kierunku systemu eksperckiego, tym wyższe koszty ${ }^{19}$. W gruncie rzeczy mieszany charakter ma też model obecnie obowiązujący, na pewnym etapie oceny czasopism minister bowiem powołuje ekspertów, którzy mają do spełnienia ważną rolę (zob. pkt IV).

\section{FUNKCJA EWALUACYJNA OBECNEGO SYSTEMU OCENY CZASOPISM - KRYTYCZNA ANALIZA OBOWIĄZUJĄCYCH ROZWIĄZAŃ}

Nowy, zgodny z regulacjami wynikajacymi z ustawy 2.0, wykaz czasopism naukowych wraz z przypisanymi im punktami został opracowany i opublikowany w 2019 r. ${ }^{20}$ Zawierał ponad 29000 tytułów czasopism, co wraz z punktowanymi materiałami konferencyjnymi (ponad 1600 pozycji) daje liczbę ponad 30600 tytułów, którym przypisano od 20 do 200 pkt. Liczba czasopism jest ujemnie skorelowana z ich waga punktowa: najmniej jest tych za 200 pkt, a najwięcej tych za 20 pkt $^{21}$. Najnowszy wykaz czasopism (z grudnia 2019 r.) obejmuje około 30400 czasopism naukowych.

Hintz, Nęcka, Prostak, Welfe ${ }^{22}$, Skoczeń ${ }^{23}$, Radwan ${ }^{24}$ oraz Kornat ${ }^{25}$ wskazują kilka ważnych cech procesu przygotowania wykazu czasopism ogłoszonego w 2019 r. oraz jego ostatecznego kształtu:

- Nastapiło radykalne zwiększenie liczby punktowanych czasopism, co wynikało z przyjęcia zasady, że podstawą wykazu ma być nie JCR, lecz rów-

\footnotetext{
19 Kulczycki (2016).

20 Skoczeń (2019).

21 Hintz et al. (2019).

22 Hintz et al. (2019).

23 Skoczeń (2019).

24 Radwan (2019).

25 Kornat (2019).
} 
nież baza Scopus, a także inne bazy: Science Citation Index Expanded, Social Sciences Citation Index, Arts \& Humanities Citation Index oraz Emerging Sources Citation Index.

- Pierwotnie przypisano czasopisma do poszczególnych dyscyplin naukowych, z której to zasady następnie jednak zrezygnowano.

- Rezygnacja z wykorzystania jednego współczynnika wpływu oraz brak jednolitych reguł tworzenia list czasopism przez 44 zespoły eksperckie doprowadziły do sytuacji, w której czasopisma należące do kilku dyscyplin otrzymywały niejednolitą wycenę punktowa, co z punktu widzenia prawidłowego działania systemu ewaluacji było nie do przyjęcia ${ }^{26}$.

- Komisja Ewaluacji Nauki zaproponowała ostateczną wartość punktowa tych czasopism, gdzie rozbieżność ocen ustalonych przez różne zespoły dyscyplinowe była bardzo duża, tj. przekraczała dwa progi punktowe (np. 140, 40, 70). Rozwiazanie to dotyczyło około 700 tytułów.

- W przypadku części czasopism (czasopisma z programu WCN i z ERIH+) wystapiły problemy z oceną punktową wynikające z nierzetelności uzasadnień zespołów dyscyplinowych, które wymagały interwencji Komisji Ewaluacji Nauki.

- Do silnych stron nowego wykazu czasopism należy zaliczyć to, że jest on obszerniejszy, bardziej zrównoważony, nieograniczony do języka angielskiego i niepodporządkowany ślepo wskaźnikowi impact factor. Słabą strona jest natomiast niezrealizowany we wszystkich zasadnych przypadkach postulat ustalenia dyscyplin głównych, gdy rozbieżność punktacji wynosi dwa progi.

- Nierzadko występującym nieporozumieniem ze stosowaniem wykazu czasopism mającego służyć ocenie instytucjonalnej jednostek naukowych jest jego mechaniczne wykorzystanie do oceny okresowej indywidualnych pracowników nauki.

Jednym z najsilniej krytykowanych elementów pełnienia przez obecny system oceny czasopism funkcji ewaluacyjnej jest przejęte w uzasadnieniu ustawy 2.0 założenie, że podstawą ewaluacji ma być: „uznanie funkcjonujaccej od ponad pół wieku w naukometrii zasady dziedziczenia prestiżu” wydawnictwa lub czasopisma, wyrażającej się tym, że artykuł naukowy jest wart tyle, ile czasopismo, w którym jest opublikowany, a monografia jest warta tyle, ile wydawnictwo ją wydające" ${ }^{27}$. Podejście to skrytykował już na etapie przygotowywania projektu rozporządzenia Ministra Nauki i Szkolnictwa Wyższego $\mathrm{w}$ sprawie sporządzania wykazów wydawnictw, monografii naukowych oraz czasopism naukowych i recenzowanych materiałów z konferencji międzyna-

${ }^{26}$ Należy tutaj wskazać na obiektywny chyba brak możliwości znalezienia jednolitego sposobu oceny czasopism wielodyscyplinowych. W stosunku do czasopism jednodyscyplinowych znajdują się one w gorszej sytuacji. W jednym i drugim przypadku potrzebny jest inny nakład pracy redakcji. Trudno jest utrzymać wysoki poziom czasopisma wielodyscyplinowego. Uśrednianie oceny zawsze będzie nieobiektywne. Wydaje się, że czasopisma wielodyscyplinowe mają z tych powodów mniejsze szanse na uzyskanie satysfakcjonującej oceny. Ale bez nich nauka bardzo ucierpiałaby, gdyż między innymi one kreują na przykład badania interdyscyplinarne.

${ }^{27}$ Druk Sejmowy nr 2446: 56. 
rodowych Andrzej K. Wróblewskii ${ }^{28}$, który podkreślił znaczenie i adekwatność oceny eksperckiej. Podobne stanowisko w sprawie tzw. zasady dziedziczenia prestiżu przez czasopisma naukowe zajęli Jakub Zakrzewski i Karol Życzkow$\mathrm{ski}^{29}$. Wydaje się, że krytyka rozważanej zasady przedstawiona przez Wróblewskiego, Zakrzewskiego i Życzkowskiego jest nadmierna oraz że prawdopodobnie w znacznej części wynika z niezrozumienia różnic w ewaluacji systemowej jednostek naukowych oraz w ewaluacji osiagnnięć indywidualnych poszczególnych naukowców. W tym drugim przypadku priorytet oceny eksperckiej nad mechanicznym podliczeniem punktów nie powinien podlegać dyskusji ${ }^{30}$.

Z kolei Włodzisław Duch ${ }^{31}$ wskazuje na potrzebę świadomego powiązania listy czasopism z polityką naukową państwa wraz z jednoczesnym uwzględnieniem specyfiki różnych dyscyplin. Autor ten buduje następującą rekomendację: „Nie możemy działać na ślepo, trzeba przeanalizować dokładnie wpływ punktacji czasopism na politykę naukową i jasno określić, które specjalności uznajemy za mało istotne. Zdefiniowanie homogenicznych grup tematycznych i odpowiednia normalizacja punktacji czasopism jest kluczową sprawą dla rozwoju nauki w Polsce" ${ }^{32}$. Duch ${ }^{33}$ wskazuje też na niebezpieczeństwo petryfikacji nauki, zauważając: „To jest ważne zagadnienie: nadając punkty czasopismom, zachęcamy, by pracować w dobrze rozwiniętych gałęziach nauki. Jak możemy promować nowe, obiecujace kierunki, w których jest szansa, by zostać pionierami?"34.

Szczegółowe uwagi krytyczne pod adresem obowiązującego systemu oraz propozycje zmian zgłosił także Michał Kokowski ${ }^{35}$. Stwierdza on, że Konstytucja dla nauki powinna mieć solidne podstawy naukowe, a jednocześnie zauważa, że tak jednak nie jest w jej kluczowym elemencie, jakim jest ewaluacja dokonań naukowych. Następnie podważa szereg przyjętych rozwiązań, silnie kwestionując między innymi wspomnianą już zasadę dziedziczenia prestiżu przez czasopisma i wydawnictwa.

Jerzy Wilkin ${ }^{36}$ zwraca uwagę na szereg zjawisk o charakterze patologicznym, które są związane z wprowadzanym systemem ewaluacji działalności naukowej. Do najważniejszych z nich zalicza następujące okoliczności: nerwowa restrukturyzacja zatrudnienia w jednostkach naukowych, komercjalizacja pu-

\footnotetext{
28 Wróblewski (2018).

29 Życzkowski (2018). Dyskusję na temat zasady dziedziczenia prestiżu wywołało stwierdzenie zawarte w uzasadnieniu projektu rozporządzenia Ministra Nauki i Szkolnictwa Wyższego w sprawie sporządzania wykazów wydawnictw z 30 lipca 2018 r.: „Obowiązuje zasada dziedziczenia prestiżu: artykuł w czasopiśmie naukowym jest wart tyle, ile czasopismo, w którym został opublikowany".

${ }^{30} \mathrm{O}$ możliwych meandrach w wykorzystaniu naukometrii i bibliometrii do oceny działalności naukowej instytucji, zespołów badawczych oraz poszczególnych pracowników w interesujący sposób pisze Wróblewski (2017).

${ }_{31}$ Duch (2018), (2020).

32 Duch (2018).

${ }_{33}$ Duch (2019), (2020).

34 Duch (2019): 4.

35 Kokowski (2018).

36 Wilkin (2020).
} 
blikacji, stres i frustracja wśród dużej części pracowników naukowych, dominacja krótkookresowości w polskim systemie funkcjonowania nauki, w tym w ocenie badaczy, niestabilność finansowania, punktoza itp. Zdaniem Wilkina ocena wprowadzanej reformy nie wypada pozytywnie, co oddają następujące słowa: „W przygotowywanej przez kilka lat z inicjatywy ministra J. Gowina i przy dużym zaangażowaniu znacznej części środowiska akademickiego reformie szkolnictwa wyższego i nauki skoncentrowano się na zmianach strukturalnych, układzie kompetencji decyzyjnych, sposobach oceny pracowników i jednostek naukowych, a w niewielkim stopniu zadbano o warunki finansowe i organizacyjne, sprzyjające wyborowi różnorodnych ścieżek rozwoju badań i karier naukowych, elastyczności sposobów oceniania, bezpieczeństwu zatrudnienia”37. Wilkin pesymistycznie patrzy także w przyszłość, podkreślając: „Na horyzoncie pojawiaja się propozycje kolejnych reform, zwłaszcza likwidacji Polskiej Akademii Nauk, co nie wzmacnia niezbędnej stabilności i przewidywalności warunków rozwoju prawie 70 instytutów PAN i zatrudnionych tam osób. Przeznaczając na badania naukowe 1\% PKB, próbuje się przez takie zabiegi zbudować w Polsce naukę na poziomie światowym" 38 .

Należy wreszcie podnieść kilka problemów, które tylko pozornie moga być uznane za mające wyłacznie techniczny charakter ${ }^{39}$. Wykorzystanie list czasopism punktowanych w polskim systemie ewaluacji działalności naukowej stało się dobra tradycją i podlegało procesowi doskonalaccej ewolucji. Listy czasopism punktowanych tworzono od lat dziewięćdziesiątych i były one zawsze podstawą ewaluacji osiagnięć w przekroju jednostek prowadzacych działalność naukowa, a obecnie w odniesieniu do dyscyplin. Najczęściej listy były wprost lub prawie wprost wykorzystywane w ewaluacji. Dopiero jednak w obecnie wdrażanym systemie stały się one podstawą do skomplikowanych obliczeń z zastosowaniem administracyjnie narzuconych ograniczeń. W ten sposób o ocenie aktywności naukowej w dużym stopniu decydują wyliczane parametry, co zachęca do stosowania ,sztuczek” związanych z tzw. optymalizacją. Niektóre uczelnie i instytuty niemało uwagi poświęcają przesunięciom pracowników na etaty dydaktyczne, zmianom przyporządkowania dyscyplinowego, dopasowywaniu współautorów itp. z myślą o tym, aby uzyskać jak najlepsze rezultaty wyliczeń. W środowisku często krytykuje się administracyjne ograniczenie aktywności najefektywniejszych pracowników i duże możliwości manipulacji doborem współautorów. Z kolei pracownicy obawiają się obserwowanej już obecnie na uczelniach oceny wartości pracy badawczej głównie pod kątem przydatności ewaluacyjnej.

Wspomniana optymalizacja jest skomplikowana, dla zdecydowanej większości pracowników nauki niezrozumiała i wymagająca wysiłku uczelni, przy czym im większa uczelnia, tym sprawa jest trudniejsza, ale jednocześnie dająca wiele możliwości optymalizacyjnych. Tadeusz Wawak pisze o tym w następujący sposób: „Przyjęty i opisany w rozporządzeniu system ewaluacji dzia-

\footnotetext{
37 Wilkin (2020): 1.

38 Wilkin (2020).

39 Na problemy te zwrócił uwagę autorów prof. Zabel.
} 
łalności naukowej jest zbyt skomplikowany, nadmiernie unaukowiony oraz po części w niektórych kwestiach: uznaniowy, nietransparentny i nieprzejrzysty. Wszystko to czyni go niezrozumiałym dla większości naukowców oraz pozostałych pracowników uczelni i instytutów badawczych, w tym głównie zarządzających tymi podmiotami objętymi ewaluacja” ${ }^{40}$. Trudności w prowadzeniu wspomnianych symulacji optymalizacyjnych są wykorzystywane przez wiele firm komercyjnych, które oferuja prace analityczne, wskazując, jak „dopasować się" do konkurencji ewaluacyjnej. Sęk jednak w tym, że nie znając wyników całej dyscypliny, takie dopasowanie jest w zasadzie bardzo ograniczone. Pomoc firm nie jest złem samym w sobie, ale może dojść do sytuacji, w których wygrają nie lepsi, ale bardziej „dopasowani”.

Wskazane okoliczności moga przyczynić się do niskiego stopnia zrozumienia obwiązujących reguł przez najbardziej zainteresowanych, czyli pracowników nauki, co może doprowadzić do ich ograniczonej identyfikacji z obowiązującym systemem, a to z kolei wiąże się z ryzykiem osłabienia jego funkcji motywacyjnej.

Zasadna jest więc konstatacja, że obecny system ewaluacji nie jest wolny od słabości, i to zarówno tych, które można określić jako kardynalne o charakterze koncepcyjnym, jak i tych, które zdają się mieć charakter bardziej techniczny. Autorzy wychodzą z założenia, że tylko pełna i kompleksowa diagnoza tych niedomagań może stanowić podstawę do zaproponowania bazujących na rzeczywistości rekomendacji na przyszłość.

\section{REKOMENDACJE - RADYKALNA ZMIANA CZY USPRAWNIENIA?}

Przedstawione w poprzednim punkcie uwagi krytyczne na temat spełniania funkcji ewaluacyjnej przez obowiazujący obecnie system oceny czasopism prowadzą do zadania kluczowego pytania: Czy w tej sytuacji wskazane byłoby podjęcie prac idących w kierunku przygotowania radyklanej zmiany, czy też należy raczej zaproponować rozwiązania usprawniające i doskonalące obecny system?

\section{Na czym miałaby/ mogłaby polegać radykalna zmiana?}

Jak stwierdzono wcześniej, obecnie obowiązujący w Polsce system ewaluacji działalności naukowej bazuje na dążeniu do precyzyjnej kwantyfikacji dorobku. W tym sensie można uznać, że twórcy reformy z 2018 r. zdecydowali się na wprowadzenie rozwiązania dość radykalnego, krytykowanego właśnie za przyjęcie założenia o możliwości ilościowego scharakteryzowania poszczególnych elementów osiagnięć i możliwości ich sprowadzenia do wspólnego mianownika. Przyjęte przez ustawodawcę rozwiązania normatywne w ustawie 2.0

${ }^{40}$ Wawak (2021). 
sa w jakimś zakresie kontynuacją budowy systemu ewaluacji jednostek naukowych, rozpoczętą w Polsce jeszcze w latach dziewięćdziesiątych ${ }^{41}$. Celem przyjętych w ustawie 2.0 rozwiązań miało być wprowadzenie ujednolicenia metody oceny wszystkich kanałów publikacji ${ }^{42}$. Należy zauważyć, że przyjęta przez ustawodawcę zasada dziedziczenia prestiżu może prowadzić do marginalizacji dobrych publikacji lokowanych w czasopismach nisko punktowanych. A contrario może się zdarzyć, że w wysoko punktowanym czasopiśmie znajdzie się artykuł słaby merytorycznie, ale formalnie pozytywnie oceniony przez recenzentów i z automatu niezasłużenie odziedziczy określoną ilość punktów ${ }^{43}$.

Jednym z przykładów dość radyklanego rozwiązania, krytykowanego przez środowisko naukowe, było przyjęcie przez ustawodawcę w rozporządzeniu z 2019 r. w $§ 34$ pkt 1) podziału publikacji dla celów ewaluacji na te, które zostały opublikowane w latach 2017 i 2018, oraz na te, które zostały opublikowane w latach 2019 i $2020^{44}$. Pierwszej grupie publikacji zamierzano przypisać wartości wynikające z komunikatu Ministra Nauki i Szkolnictwa Wyższego z 25 stycznia 2017 r. w Biuletynie Informacji Publicznej. Druga zaś grupa publikacji miałaby przypisane wartości wynikające z komunikatu Ministra Nauki i Szkolnictwa Wyższego z 18 grudnia 2019 r. Takie zróżnicowane rozwiązanie wyceny dorobku naukowego jest zmiana zasad gry w trakcie gry oraz złamaniem jednej z podstawowych zasad prawa - lex retro non agit. Każdy naukowiec, planujac swoją karierę, dokonuje wyboru odpowiednich publikatorów, sądząc, że dane czasopismo przez jakiś czas zachowa swoją pozycję na liście ministerialnej. Uzyskane w ten sposób punkty za publikacje rzutuja na ocenę dorobku w postępowaniach awansowych. Tymczasem wydanie komunikatu pod koniec 2019 r. z wykazem czasopism i przypisaniem im określonych wartości w sposób znaczący wpłynęło na ocenę dorobku poszczególnych naukowców ubiegających się o awans naukowy oraz na przygotowania jednostek do planowanej wówczas ewaluacji działalności naukowej prowadzonej w ramach poszczególnych dyscyplin w 2021 r. ${ }^{45}$

Krytyka prowadzona przez liczne środowiska akademickie rozwiąań przyjętych przez ustawodawcę w ustawie 2.0 oraz rozporządzeniu z 2019 r. rodzi pytanie o to, co robić dalej. Alternatywę dla takiej koncepcji mogłyby

${ }^{41}$ Pierwsze takie próby były podejmowane w początkach lat osiemdziesiątych w Wielkiej Brytanii.

${ }^{42}$ Uzasadnienie do ustawy 2.0, druk 2446: 54.

${ }^{43}$ Jeszcze pod rządami CK, a obecnie RDN, została wznowiona sprawa pewnej habilitacji zrobionej na cyklu opublikowanych artykułów. Po kilku latach wydawcy tych artykułów wycofali je z oficjalnego obiegu, wykryto w nich bowiem liczne nieuczciwości w przeprowadzonych badaniach czy eksperymentach. Z punktu widzenia formalnego artykuły te zostały opublikowane, mimo że ich jakość merytoryczna była wątpliwa.

${ }^{44} \mathrm{Na}$ to i na inne kontrowersyjne rozwiązania przyjęte w systemie ewaluacji zwracał uwagę Wawak (2019b: 330-345), wyrażając jednocześnie pogląd, że było wystarczająco dużo czasu do pierwszej ewaluacji, aby naprawić zasygnalizowane nieprawidłowości.

45 Liczba punktów przyznana publikacjom za lata 2017 i 2018 nie zmieniła się zasadniczo również po nowelizacji przedmiotowego rozporządzenia przez rozporządzenie Ministra Nauki i Szkolnictwa Wyższego zmieniające rozporządzenie w sprawie ewaluacji jakości działalności naukowej z 31 lipca 2020 r. (Dz. U. 2020, poz. 1352). Sama zaś ewaluacja dyscyplin naukowych została przesunięta na rok 2022. 
stanowić dwa rozwiązania. Pierwsze z nich to przesunięcie ciężaru ewaluacji na ocenę ekspercka, a drugie to ewolucyjna modyfikacja, doskonalenie i racjonalizacja obecnych rozwiązań. Pierwszemu rozwiązaniu poświęcono uwagę $\mathrm{w}$ tym podpunkcie, a w drugim zajęto się w kolejnym.

Model eksperckiej oceny czasopism występuje w licznych państwach europejskich. Na przykład w dyscyplinie nauk prawnych nie stosuje się wskaźników bibliometrycznych do budowy rankingów czasopism prawniczych m.in. we Francji, Niemczech, Austrii i w Szwajcarii. Z kolei w Wielkiej Brytanii nie są wykorzystywane amerykańskie rankingi czasopism prawniczych. Państwa te zbudowały własny, ekspercki model oceny czasopism naukowych ${ }^{46}$.

Model eksperckiej oceny czasopism nie jest jednak pozbawiony pewnych dysfunkcjonalności. Należy przyjąć, że główną słabością propozycji szerokiego wykorzystania oceny eksperckiej w ewaluacji działalności naukowej sa jej koszty $^{47}$. W wersji skrajnej, zakładającej wykorzystanie do ewaluacji wybitnych ekspertów zagranicznych, proponowanie tego wariantu należałoby uznać za nierealistyczne. $\mathrm{Z}$ podobnych względów nie wydaje się możliwe uznanie za wykonalne rozwiązania zakładającego oparcie podobnej oceny na ekspertach krajowych. W tej sytuacji, kierując się poczuciem realizmu, więcej uwagi należy poświęcić podejściu ewolucyjnemu, przyjmującemu za punkt wyjścia obecnie obowiązujące rozwiązania. Podsumowując rozważania na temat potencjału szerokiego wykorzystania oceny eksperckiej, należy zauważyć, że nie byłoby ono możliwe na gruncie obowiązującej ustawy $2.0^{48}$.

Drugim argumentem przemawiajacym jedynie za pomocniczym charakterem stosowania oceny eksperckiej do ewaluacji czasopism naukowych jest brak szerokiej grupy doświadczonych ekspertów, którzy w sposób obiektywny i niezależny dokonaliby takiej oceny. W praktyce ewaluacyjnej ministrowie właściwi do spraw szkolnictwa wyższego i nauki powołują doraźne grupy eksperckie do oceny czasopism. Sa to jednak grupy eksperckie powoływane najczęściej z nadania politycznego. Stąd obecność niektórych czasopism na liście ministerialnej budzi zdziwienie w środowiskach naukowo ugruntowanych.

W końcu dysfunkcja modelu eksperckiej oceny czasopism w Polsce jest niewątpliwie obrona pozycji starszych czy renomowanych czasopism lub też czasopism wydawanych przez duże jednostki naukowe czy badawcze. Ugruntowując istniejacy status quo, praktycznie zamyka się możliwość rozwoju nowym inicjatywom publikacyjnym, zwłaszcza w nowych czy mniejszych ośrodkach akademickich.

\section{Podejście ewolucyjne}

Prowadzona w licznych artykułach krytyka przyjętych w ustawie 2.0 rozwiązań dotyczących procesów ewaluacji dyscyplin naukowych i czasopism naukowych rodzi ontologiczne pytanie: Jak zatem być powinno? Niewątpliwie

\footnotetext{
46 Wierczyński (2020): 7.

47 Kulczycki (2016).

48 Hintz et al. (2019).
} 
z analizy literatury przedmiotu wynika, że co do zasady środowisko naukowe neguje drogę rewolucyjnych zmian systemu, jakie wprowadzono na przykład podczas reformy szkolnictwa wyższego w 2011 r. czy obecnie na podstawie ustawy 2.0 w 2018 r. Bardziej akceptowalna jest zatem droga wprowadzania ewolucyjnych zmian, a więc poprawiania istniejącego już systemu tam, gdzie to jest konieczne.

Ranking czasopism nie tylko nie powinien działać z mocą wsteczna, ale powinien być stabilny i wiarygodny. Wiarygodność rankingu zależy od danych, na jakich został oparty, oraz od procedur, w jakich został opracowany. Trafne jest zatem oparcie tego rankingu na danych bibliometrycznych i na ocenie zespołów eksperckich (system mieszany). Konieczne jednak jest doprecyzowanie zasady zbierania danych, na podstawie których powstaje lista czasopism. Stabilność rankingu zależy od permanentnej oceny czasopism naukowych, nie zaś periodycznej, dokonywanej raz na jakiś czas. Konieczne jest zatem utworzenie trwałych zespołów, które w sposób ciagły dokonywałyby oceny czasopism.

Kokowski ${ }^{49}$ zauważył, że zasada dziedziczenia prestiżu przyjęta przez ustawodawcę w ustawie 2.0 nie jest powszechnie znana i stosowana w innych krajach. Jest ona narzucana przez lobby właścicieli wielkich międzynarodowych baz indeksacyjnych. Ponadto nie wszystkie kraje europejskie, w tym Wielka Brytania, buduja swoje rankingi czasopism na podstawie wskaźników naukometrycznych rekomendowanych przez bazy międzynarodowe (np. Scopus czy Web of Science).

Wydaje się, że właściwsze byłoby budowanie systemu oceny czasopism naukowych opierającego się na polskich doświadczeniach, nie tracąc jednocześnie kontaktu z otoczeniem międzynarodowym. Kokowski już w 2018 r. zaproponował, aby nie likwidować listy A i C, które istniały do 2019 r. Międzynarodowe kryteria oceny, w tym IF należałoby stosować w odniesieniu do czasopism z listy A. Byłyby to czasopisma z dziedziny nauk inżynieryjno-technicznych, nauk rolniczych, nauk medycznych i o zdrowiu, nauk ścisłych i przyrodniczych. Na tej liście powinny znaleźć się również czasopisma zagraniczne. Z kolei na liście B mogłyby znajdować się czasopisma z dziedzin nauk humanistycznych, nauk społecznych, nauk teologicznych i z dziedziny sztuki. Czasopisma z zakresu poszczególnych dyscyplin zaliczonych do listy B mogłyby również aplikować do listy A (np. czasopisma z nauk o zarządzaniu i jakości czy ekonomii i finansów). Zresztą podobny model istnieje we Włoszech ${ }^{50}$. W ten sposób polskie publikacje z wielu dyscyplin mogłyby być znane i cenione w kręgu międzynarodowym z jednoczesnym zachowaniem rodzimej specyfiki badań i badanych problemów.

W końcu można zasugerować ustawodawcy, aby przy okazji rozpoczęcia konsultacji przez Ministra Edukacji i Nauki nad projektem rozporządzenia z 29 grudnia 2020 r. w sprawie programu „Rozwój czasopism naukowych” $\mathrm{w}$ drodze ewolucji wprowadzić instrumenty pozwalające na podniesienie jakości czasopism naukowych przy jednoczesnym zmniejszeniu ich liczby. W ra-

\footnotetext{
49 Kokowski (2018).

50 Wierczyński (2020): 11.
} 
mach programu „Rozwój czasopism naukowych” ustawodawca mógłby zaproponować wydawcom czasopism bonus finansowy za dobrowolne połączenie się przynajmniej dwóch czasopism. Dodatkowo ustawodawca mógłby zaproponować wydawcom czasopism podniesienie punktacji do wyższego poziomu za połączenie czasopism. Możliwość skorzystania z obu bonusów byłaby otwarta tylko dla czasopism, które znalazłaby się na liście Ministerstwa oraz mają tę samą liczbę przyznanych punktów przez ekspertów. Podwyższona punktacja mogłaby obowiązywać przejściowo (np. dwa lata), po czym następowałby powrót do powszechnie przyjętych zasad punktacji.

\section{ZAKOŃCZENIE}

Zawarte wyżej rozważania upoważniają do wysunięcia kilku wniosków. Po pierwsze, przeprowadzona analiza wykazała, że czasopisma spełniaja w systemie nauki i szkolnictwa wyższego liczne funkcje, których nie daje się ograniczyć wyłącznie do funkcji narzędzia służącego do ewaluacji osiagnięć naukowych. Po drugie, obecny kształt funkcji ewaluacyjnej czasopism został ukształtowany w trakcie około 30-letniego procesu ewolucji systemu działania nauki i szkolnictwa wyższego w Polsce, procesu zainicjowanego na początku lat dziewięćdziesiątych XX w., po rozpoczęciu kompleksowej transformacji modelu społeczno-gospodarczego. Po trzecie, wydaje się, że mieszcząc się w ramach przyjętych rozwiązań zapisanych w ustawie 2.0, uzasadnionym kierunkiem rozwoju przyjętej roli czasopism jest stopniowe, ewolucyjne doskonalenie ich funkcji ewaluacyjnej - wskazane słabe strony systemu ewaluacji nauki w ogólności i ewaluacji czasopism w szczególności nie mają bowiem charakteru fundamentalnego i stosunkowo niewielkim wysiłkiem mogą być poddane procesowi racjonalizacji.

Autorzy niniejszego opracowania przyjęli założenie, aby prowadzone rozważania ograniczyć do zagadnień związanych z czasopismami. W tym kontekście można oczywiście zaproponować, by podobną analizę przeprowadzić także w odniesieniu do monografii i wydawnictw, jako drugiego komponentu składającego się na poziom naukowy lub artystyczny prowadzonej działalności.

Duch, W. (2018). Naukowa ślepota. PAUza Akademicka 435: 2-3.

Duch, W. (2019). Hamulce rozwoju nauki: ocena czasopism. PAUza Akademicka 470: 4.

Duch, W. (2020). Hamulce rozwoju. Głos Uczelni. Czasopismo Uniwersytetu Mikołaja Kopernika w Toruniu 397(3/4): 22-26.

Gorynia, M. (2021). Przedsiębiorstwo w biznesie międzynarodowym - aspekty ekonomiczne, finansowe i menedżerskie. Warszawa: Wydawnictwo Naukowe PWN.

Gorynia, M., Jankowska, B. (2017). O tożsamości biznesu międzynarodowego, [w:] M. Maciejewski, K. Wach (red.), Handel zagraniczny i przedsiębiorczość międzynarodowa we współczesnej gospodarce: 127-142. Kraków: Uniwersytet Ekonomiczny w Krakowie.

Hintz, M., Nęcka, E., Prostak, R., Welfe, A. (2019). Jak powstał nowy wykaz czasopism naukowych. Forum Akademickie 11.

Hofman, I. (2017). Czasopisma towarzystw naukowych w ujęciu medioznawczym, [w:] A. Kansy (red.), Czasopisma towarzystw naukowych w Polsce. Tom 1: 15-24. Warszawa: Polska Akademia Nauk: 15-24. 
Kansy, A. (red.) (2017). Czasopisma towarzystw naukowych w Polsce. Warszawa: Polska Akademia Nauk.

Kokowski, M. (2018). Podstawowe zastrzeżenia wobec projektu i uchwalonej Ustawy 2.0 vel Konstytucji dla nauki. Studia Historiae Scientiarum 17: 453-476. <http://pau.krakow.pl/SHS/ shs-17-2018-16.pdf>.

Kornat, M. (2019). W sprawie punktacji czasopism historycznych. Forum Akademickie 7/8.

Kozłowski, J. (2010). Ewaluacja instytucji naukowych w Polsce w świetle porównań międzynarodowych i konsultacji. Ministerstwo Nauki i Szkolnictwa Wyższego. <http://www.bip.nauka.gov. pl/g2/oryginal/2013_05/3a02095daebdd8dc209cbe685db7e560.pdf> [dostęp: 3.01.2021].

Kulczycki, E. (2016). Krajowy system oceny publikacji. Dr hab. Emanuel Kulczycki podczas panelu System publikowania w NSH - w poszukiwaniu porównywalności. Forum Akademickie 12.

Kulczycki, E. (2019). Tajemnice bibliometrii. Rozmowa z dr. hab. Emanuelem Kulczyckim, prof. UAM, specjalista w dziedzinie bibliometrii i ewaluacji nauki. Forum Akademickie 6.

Kulczycki, E., Rozkosz E., Drabek, A. (2016). Ocena ekspercka jako trzeci wymiar ewaluacji krajowych czasopism naukowych. Nauka 1: 107-142.

Radwan, J. (2019). Punktacja czasopism naukowych. Refleksje z prac zespołu nauk biologicznych. Forum Akademickie 6.

Skoczeń, B. (2019). Pierwsze kroki ku ewaluacji jakości nauki. Forum Akademickie 11.

Wierczyński, G. (2020). Problemy oceny parametrycznej polskich czasopism naukowych z dziedziny nauk prawnych. Państwo i Prawo 75(9): 3-22.

Wilkin, J. (2020). Nauka traci swą duszę, a my radość z jej uprawiania. PAUza Akademicka 519: $1-2$.

Wróblewski, A.K. (2017). Nie wszystko, co się liczy, da się policzyć... Nauka 1: 7-22.

Wróblewski, A.K. (2018). Zatruty prezent na stulecie niepodległości Polski. PAUza Akademicka 435: 2.

Wawak, T. (2019a). Doskonalenie jakości zarządzania w szkołach wyższych. Kraków: Wydawnictwo Uniwersytetu Jagiellońskiego.

Wawak, T. (2019b). Ewolucja uwarunkowań jakości zarządzania w szkołach wyższych w Polsce w latach 1918-2018. Kraków: Wydawnictwo Uniwersytetu Jagiellońskiego.

Wawak, T. (2021). Upravlìnnâ âkìstû ta âkìst' upravlìnnâ u viŝih navčal'nih zakladah ta ocìnka âkosti naukovoï diâl'nosti v Pol'ŝì [Zarządzanie jakością i jakość zarządzania w szkołach wyższych oraz ewaluacja jakości działalności naukowej w Polsce], [w:] D.G. Luk'ânenko, L.L. Antonûk (red.), Konkurentnì modelì upravlìnnâ âkìstû viŝoï osvìti v XXI stolìttì. Kiev.

Zakrzewski, J., Życzkowski, K. (2018). Przeciw dziedziczeniu ,prestiżu”. PAUza Akademicka 440: 2.

\section{THE ROLE OF SCIENTIFIC JOURNALS IN THE REFORMED SYSTEM OF SCIENCE AND HIGHER EDUCATION IN POLAND}

Sum mary

A triple goal was set for this article: (i) identifying the functions fulfilled by scientific journals in the system of science and higher education in Poland; (ii) diagnosis and assessment of the performance of the evaluation function by the current system of journal evaluation - a critical analysis of the applicable solutions; (iii) outlining the directions of the evolution of the journal evaluation system in Poland. As far as the methodology is concerned, a critical analysis of the literature on the subject as well as a critical analysis and evaluation of applicable legal regulations played a leading role. Moreover, elements of the diagnostic approach (the description and assessment of existing solutions) and the prognostic/ prospective approach (an outline of proposed changes to existing solutions) were used in the considerations. Additionally, the work uses the method of legal and dogmatic analysis of legal provisions, which allows for a critical assessment of the legislator's intentions.

Keywords: scientific journals; system of science and higher education in Poland; functions of scientific journals; evaluation of scientific journals 
